\title{
Keanekaragaman Siput Ordo Mesogastropoda dan Neogastropoda pada Zona Eulitoral di Kawasan Pesisir Pulau Sembilan, Kabupaten Kotabaru
}

\author{
Hery Fajeriadi*, Muhammad Zaini, Dharmono \\ Program Studi Magister PendidikanBiologi, Program Pascasarjana, FakultasKeguruandanIlmuPendidikan, \\ UniversitasLambungMangkurat \\ Jl. Brigjend. H. HasanBasry, Kota Banjarmasin, 70123 \\ Email: heryfaje@gmail.com
}

\begin{abstract}
Abstrak
Gastropoda tersebar luas di kawasan pesisir, salah satunya pesisir Pulau Sembilan Kotabaru. Kawasan ini masih tergolong alami dan terdapat terumbu karang. Beberapa titik terumbu karang mulai mengalami kerusakan. Terumbu dan batu karang di zona eulitoral merupakan habitat alami gastropoda. Gastropoda terbagi menjadi tiga ordo, dua diantaranya adalah Ordo Mesogastropoda dan Ordo Neogastropoda belum didokumentasikan. Penelitian ini bertujuan untuk melanjutkan dokumentasi spesies gastropoda (Mesogastropoda dan Neogastropoda) dan menganalisis indeks keanekaragamannya. Data dikumpulkan dengan teknik purposive sampling dengan luas plot $1 \mathrm{~m}^{2}$, sebanyak 20 plot, di sepanjang seratus meter mengikuti garis pantai. Data yang dikumpulkan adalah nama spesies dan jumlah individu setiap spesies. Berdasarkan data tersebut ditentukan indeks keanekaragaman menggunakan persamaan Shannon-Wienner. Ditemukan lima spesies dari Ordo Mesogastropoda dan dua spesies dari Ordo Neogastropoda.Indeks keanekaragaman (H') Mesogastropoda dan Neogastropoda adalah 1.620 dengan kategori sedang, artinya ekosistem di kawasan tersebut tergolong stabil.
\end{abstract}

Kata Kunci: Keanekaragaman; Mesogastropoda; Neogastropoda; Pesisir; Kotabaru

\section{Abstract \\ Snails Diversity of Mesogastropod and Neogastropod Order at the Eulittoral Zone of Coastal Area Pulau Sembilan, Kotabaru Regency}

Gastropods are widespread in the coastal area, one of which is the coast of Pulau Sembilan Kotabaru. This area is still relatively natural, and there are coral reefs. Some points of coral reefs began to suffer damage. Reefs and rocks in the eulittoral zone are natural gastropod habitats. Gastropods are divided into three orders, two of which are mesogastropod orders, and the neogastropod order has not been documented. This study aims to continue the documentation of gastropod species (Mesogastropods and Neogastropods) and analyze their diversity index. Data were collected by purposive sampling technique with a plot area of $1 \mathrm{~m} 2$, as many as 20 plots, along a hundred meters following the coastline. The data collected is the name of the species and the number of individuals in each species. Based on these data the diversity index is determined using the Shannon-Wiener equation. Five species of the mesogastropod order and two species of the neogastropod order were found. The Mesogastropod and Neogastropod diversity index $\left(H^{\prime}\right)$ is 1,620 in the medium category, meaning that the ecosystem in the region is classified as stable.

Keywords: Diversity; Mesogastropod; Neogastropod; Coastal; Kotabaru

\section{PENDAHULUAN}

Gastropoda merupakan hewan bertubuh lunak, kadang memiliki cangkang tunggal (univalvia) atau tidak memiliki cangkang (siput telanjang). Gastropoda tersebar luas, terutama di lingkungan lahan basah. Salah satu tipe ekosistem lahan basah yang banyak dihuni oleh gastropoda adalah kawasan pesisir (Coastal area). Menurut Brown \& Lydeard (2010), Gastropoda adalah kelas paling beragam dari Filum Mollusca, terdiri hampir tiga perempat dari sekitar 110.000 spesies moluska yang dikenal. Lebih dari 50.000 spesies ini sebagian besar berasal dari laut dan air tawar.

Ekosistem terbesar bumi terdapat di perairan dan daratan, keduanya dihubungkan oleh ekosistem peralihan, yaitu ekosistem pesisir. Kawasan pesisir berdasarkan kadar airnya dibagi dua, yaitu area kering dan area basah. Area kering 
masih dipengaruhi oleh angin laut, pasang surut dan intrusi garam. Area basah dipengaruhi oleh aktivitas darat, sedimentasi dan air tawar. Terumbu karang dan padang lamun adalah dua dari tiga ekosistem yang memiliki peran ekologis penting di wilayah pesisir, diantaranya sebagai habitat dan penahan gelombang terutama pada zona eulitoral.

Zona eulitoral adalah zona antara, artinya terendam saat pasang dan kering saat surut. Salah satu satwa yang ditemukan di zona eulitoral adalah gastropoda, atau lebih dikenal sebagai siput oleh masyarakat luas (Goltenboth et al., 2012). Zona eulitoral yang masih alami tentu menjadi habitat yang baik bagi berbagai spesies gastropoda, dan ancaman pada zona tersebut berdampak secara signifikan terhadap habitat dan persebaran gastropoda.

Kawasan pesisir di Kalimantan Selatan yang masih alami diantaranya kawasan pesisir Pulau Sembilan Kabupaten Kotabaru. Keanekaragaman gastropoda yang telah didata di kawasan tersebut adalah dari ordo archaeogastropoda. Melalui observasi di zona eulitoralnya, Fajeriadi et al. (2018a) menemukan 12 spesies archaeogastropoda, terdiri atas Nerita fulgurans; $N r$. semirugosa; $N r$. polita; $N r$. insculpta; Nr. plicata; Monodonta labio; Mo. canalifera; Echinolittorina jamaicensis; Fissurella nimbosa; Fi. barbadensis; Patella sp.; dan Pa. rustica.

Dokumentasi keanekaragaman hayati perlu dilakukan mengingat mulai banyaknya ancaman keberadaan makhluk hidup di kawasan pesisir Pulau Sembilan Kotabaru. Menurut Soni \&
Thakur (2015) penelitian awal komunitas diperlukan sebagai bahan pertimbangan dalam menentukan strategi konservasi dan manajemen spesifik lokasi. Penelitian ini merupakan studi lanjutan dari penelitian Fajeriadi et al. (2018a) tentang keanekaragaman siput ordo archaeo gastropoda di zona eulittoral kawasan pesisir Pulau Sembilan Kotabaru, sehingga tujuan penelitian ini adalah mengidentifikasi jenis siput ordo mesogastropoda dan neogastropoda, serta menentukan indeks keanekaragamannya.

Penelitian ini bertujuan mengidentifikasi jenis - jenis siput ordo mesogastropoda dan neogastropoda di zonaeulittoral. Tujuan kedua ialah menentukan indeks keanekaragaman untuk menunjukkan struktur komunitas dan kestabilan ekosistem di sekitarnya.

\section{MATERI DAN METODE}

Penelitian ini adalah penelitian deskriptif menggunakan teknikPurposive Sampling. Titik sampel ditentukan berdasarkan kehadiran spesimen. Jika specimen siput Mesogastropoda dan atau Neogastropoda hadir maka disanalah titik pengambilan sampel. Zonaeulitoral yang diamati mengikuti garis pantai Pulau Sembilan Kabupaten Kotabaru sepanjang seratus meter kearah tenggara dari pelabuhan utama. Setiap titik pengambilan sampel dibagi menjadi 20 titik pengambilan sampel (Gambar 1) dengan ukuran plot $1 \mathrm{~m}^{2}$. Waktu pengambilan sampel dilakukan pada pagi hari dan malam hari.

Pengambilan sampel siput dilakukan dengan mengambil perwakilan individu dengan ukuran terbesar dan terkecil pada setiap spesies.

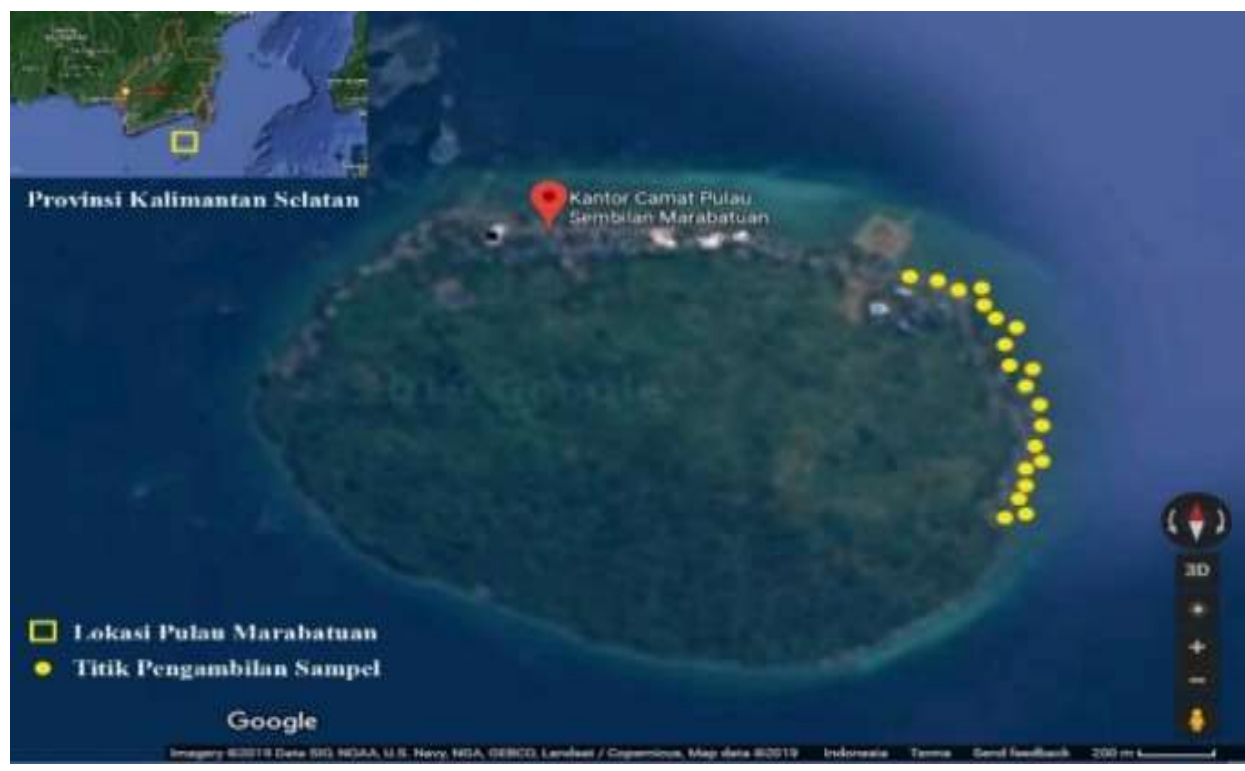

Gambar 1.Peta Lokasi Penelitian 
Sampel siput dikelompokkan berdasarkan ciri-ciri morfologi. Spesimen siput yang ditemukan kemudian dibawa ke basecamp untuk keperluan dokumentasi dan identifikasi lanjutan.

Data yang diobservasi ialah ciri morfologi dan jumlah individu setiap spesies. Analisis morfologi spesies siput dilakukan secara deskriptif, mengacu pada panduan identifikasi dari Kusnadi et al. (2008); Quintero-Galvis \& Castro (2013); dan Reidet al. (2004). Kemudian, analisis indeks keanekaragaman dilakukan melalui persamaan Shannon-Wienner (Fachrul, 2012). Kisaran Indeks Keanekaragaman adalah sebagai berikut : $0-1=$ kategori rendah; $2-3=$ kategori sedang; >3= kategori tinggi

\section{HASIL DAN PEMBAHASAN}

Berdasarkan observasi lapangan, ditemukan hasil identifikasi jenis gastropoda ordo mesogastropoda dan neogastropoda dapat dilihat pada Tabel 1, jumlah individu spesies dapat dilihat pada Gambar 2. Keberadaan spesies gastropoda di zona pesisir dipengaruhi oleh beberapa faktor, diantaranya faktor natalitas dan mortalitas. Natalitas berhubungan dengan kehidupan, sedangkan mortalitas berhubungan dengan tingkat kematian.

Faktor natalitas pada umumnya didukung oleh keberadaan makanan dan habitat. Spesies

Tabel 1.Hasil Identifikasi Spesies Gastropoda
Littoraria angulifera memiliki jumlah individu yang paling banyak karena ketersediaan makanan yang baik. Spesies ini beraktivitas di batu besar yang terendam sebagian ketika pasang, sehingga terjadi sedimentasi lumpur organik di permukaan batu. Sedimen ini menjadi sumber makanan bagi spesies tersebut. Faktor mortalitas atau kematian bagi spesies ini jarang terjadi, karena jarang dikonsumsi oleh masyarakat Pulau Sembilan. Menurut Febrita et al. (2015) dan Yanto et al. (2016) mayoritas gastropoda menyukai substrat lumpur berpasir. Tuheteru et al. (2014) sebelumnya telah menyatakan substrat dengan partikel yang besar dan karas memiliki sedikit kandungan organik, sedangkan menurut Romdhani et al. (2016) substrat dengan partikel kecil memiliki kandungan organik lebih banyak.

Berbeda halnya dengan spesies di atas, Ocinebrina aciculata dan Cypraea arabica memiliki jumlah individu paling sedikit karena kondisi habitat yang kurang sesuai. Spesiesspesies ini ditemukan beraktivitas mencari makan di terumbu dan batu karang dasar perairan. Akan tetapi kondisi terumbu karang di zona eulitoral sudah mengalami kerusakan sehingga menghambat perkembangbiakan spesies tersebut. Selain itu, Cypraea arabica juga diminati masyarakat setempat sebagai lauk pengganti ikan, sehingga meningkatkan resiko mortalitas terhadap

\begin{tabular}{lll}
\hline Ordo & Famili & Spesies \\
\hline Mesogastropoda & Strombidae & Strombus $\mathrm{sp} .1$ \\
& & Strombus $\mathrm{sp} .2$ \\
& Littorinidae & Littoraria angulifera Lamarck, 1822 \\
& Littoraria scabra Linnaeus, 1758 \\
& Cypraeidae & Ceothais marginatratra Blainville, 1832 \\
\hline Neogastropoda & Muricidae & Ocinebrina aciculata \\
\hline
\end{tabular}

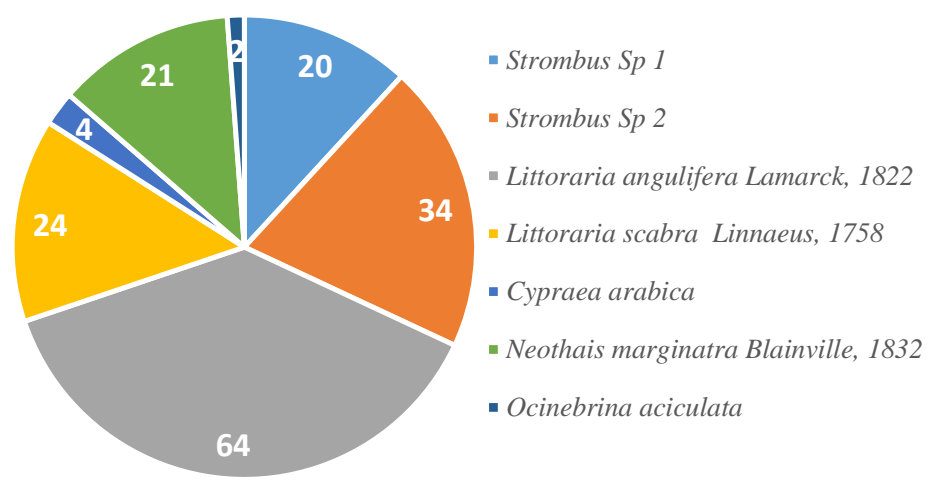

Gambar 2. Jumlah Individu Spesies 
populasi spesies tersebut. Menurut Suratissa dan Rathnayake (2017) tingkat konsumsi manusia terhadap gastropoda secara signifikan mempengaruhi tingkat populasi.

Berdasarkan distribusinya, spesies dengan jumlah individu yang paling banyak ditemukan pada batu-batu besar yang terendam sebagian ketika air laut pasang, sedangkan pada terumbu dan batu karang yang terendam di dasar perairan memiliki jumlah individu spesies yang sedikit. Menurut Kurhe et al. (2014) distribusi gastropoda di kawasan pesisir menunjukkan perbedaan zonasi. Pola distribusi vertikal terjadi pada zona pantai berbatu, kolam, dinding batu dan hubungannya dengan aspek biotik dan abiotik.

\section{Strombus sp.1}

Cangkang berjumlah satu dengan bentuk lonjong, strukturnya rapuh, dan permukaannya licin. Ukuran cangkang yaitu panjang $1,4 \mathrm{~cm}$; tinggi $0,8 \mathrm{~cm}$; dan lebar $0,8 \mathrm{~cm}$. Arah putaran cangkang ke kiri sebanyak 6 putaran. Mulut cangkang tidak bergerigi. Tidak memiliki operculum. Proboscis dengan siphon sepanjang $0,2 \mathrm{~cm}$. Ukuran siphon tidak sepanjang cangkang, yaitu $0,2 \mathrm{~cm}$. Canal siphon pendek, berukuran 0,1 $\mathrm{cm}$, berbentuk mencuat pada bagian anterior mulut cangkang. Kaki berukuran panjang $1,1 \mathrm{~cm}$, tidak memiliki bysus. Biasanya ditemukan di pesisir pantai, menempel pada batu di sepanjang garis pantai yang mengalami pasang surut.

\section{Strombus sp.2}

Cangkang berjumlah satu dengan bentuk lonjong, strukturnya kuat, dan permukaannya licin. Ukuran cangkang yaitu panjang $1,5 \mathrm{~cm}$; tinggi $0,8 \mathrm{~cm}$; dan lebar $0,9 \mathrm{~cm}$. Arah putaran cangkang ke kiri sebanyak 4 putaran. Mulut cangkang bergerigi sebanyak 6 buah. Tidak memiliki operculum. Proboscis dengan siphon sepanjang $0,2 \mathrm{~cm}$. Ukuran siphon tidak sepanjang cangkang, yaitu $0,2 \mathrm{~cm}$. Canal siphon pendek, berukuran $0,1 \mathrm{~cm}$, berbentuk mencuat pada bagian anterior mulut cangkang. Kaki berukuran panjang $0,9 \mathrm{~cm}$, tidak memiliki bysus. Biasanya ditemukan di pesisir pantai, menempel pada batu di sepanjang garis pantai yang mengalami pasang surut.

\section{Littoraria angulifera Lamarck, 1822}

Cangkang berjumlah satu dengan bentuk lonjong, strukturnya rapuh, dan permukaannya licin. Ukuran cangkang yaitu panjang $1,3 \mathrm{~cm}$; tinggi $0,8 \mathrm{~cm}$; dan lebar $0,7 \mathrm{~cm}$. Arah putaran cangkang ke kiri sebanyak 7 putaran. Mulut cangkang tidak bergerigi. Memiliki operculum berwarna coklat keemasan. Proboscis dengan siphon sepanjang $0,2 \mathrm{~cm}$. Ukuran siphon tidak sepanjang cangkang, yaitu $0,2 \mathrm{~cm}$. Tidak memiliki canal siphon. Kaki berukuran panjang $0,7 \mathrm{~cm}$, tidak memiliki bysus. Biasanya ditemukan di pesisir pantai, menempel pada batu di sepanjang garis pantai yang mengalami pasang surut.

\section{Littoraria scabra Linnaeus, 1758}

Cangkang berjumlah satu dengan bentuk lonjong, strukturnya rapuh, dan permukaannya licin. Ukuran cangkang yaitu panjang $2 \mathrm{~cm}$; tinggi $1,5 \mathrm{~cm}$; dan lebar $1,4 \mathrm{~cm}$. Arah putaran cangkang ke kiri sebanyak 4 putaran. Mulut cangkang tidak bergerigi. Memiliki operculum berwarna kuning kehijauan. Proboscis dengan siphon sepanjang 0,6 $\mathrm{cm}$. Ukuran siphon tidak sepanjang cangkang, yaitu $0,6 \mathrm{~cm}$. Tidak memiliki canal siphon. Kaki berukuran panjang $1,8 \mathrm{~cm}$, tidak memiliki bysus. Biasanya ditemukan di pesisir pantai, menempel pada batu di sepanjang garis pantai yang mengalami pasang surut.

\section{Cypraea arabica}

Cangkang berjumlah satu dengan bentuk lonjong, strukturnya kuat, dan permukaannya licin. Ukuran cangkang yaitu panjang $3,5 \mathrm{~cm}$; tinggi $2,1 \mathrm{~cm}$; dan lebar $2,9 \mathrm{~cm}$. Tidak ada putaran cangkang. Mulut cangkang bergerigi sebanyak 23 buah. Tidak memiliki operculum. Proboscis dengan siphon sepanjang $0,3 \mathrm{~cm}$. Ukuran siphon tidak sepanjang cangkang, yaitu $0,3 \mathrm{~cm}$. Canal siphon pendek, berukuran $0,1 \mathrm{~cm}$, berbentuk mencuat pada bagian anterior mulut cangkang. Kaki berukuran panjang $4,1 \mathrm{~cm}$, tidak memiliki bysus. Biasanya ditemukan di pesisir pantai, terutama menempel pada batu atau padang lamun di daerah yang selalu terendam air laut meskipun sedang surut terendah.

\section{Neothais marginatra Blainville, 1832}

Cangkang berjumlah satu dengan bentuk lonjong, strukturnya kuat, dan permukaannya berduri tumpul. Ukuran cangkang yaitu panjang $2,1 \mathrm{~cm}$; tinggi $1,2 \mathrm{~cm}$; dan lebar $1,3 \mathrm{~cm}$. Arah putaran cangkang ke kiri sebanyak 4 putaran. Mulut cangkang bergelombang sebanyak 4 buah. Operculum berwarna hitam dengan pinggiran berwarna coklat kemerahan. Proboscis dengan siphon sepanjang $0,3 \mathrm{~cm}$. Ukuran siphon tidak sepanjang cangkang, yaitu $0,3 \mathrm{~cm}$. Canal siphon pendek, berukuran $0,2 \mathrm{~cm}$, berbentuk mencuat 


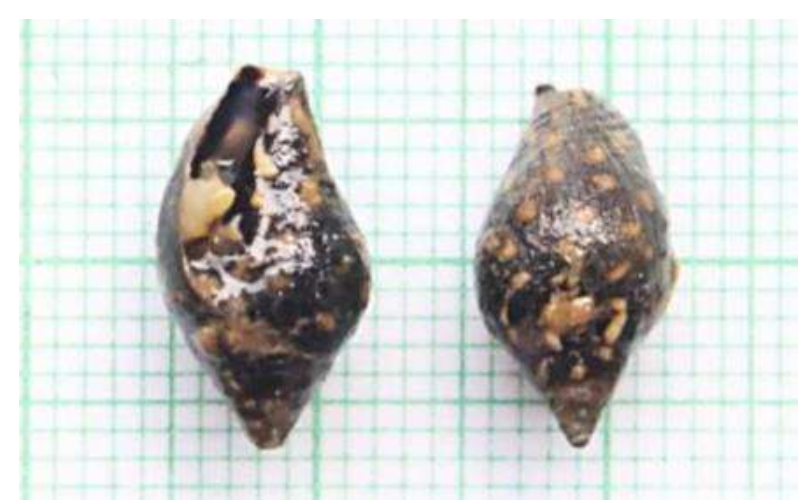

Strombus sp. 1

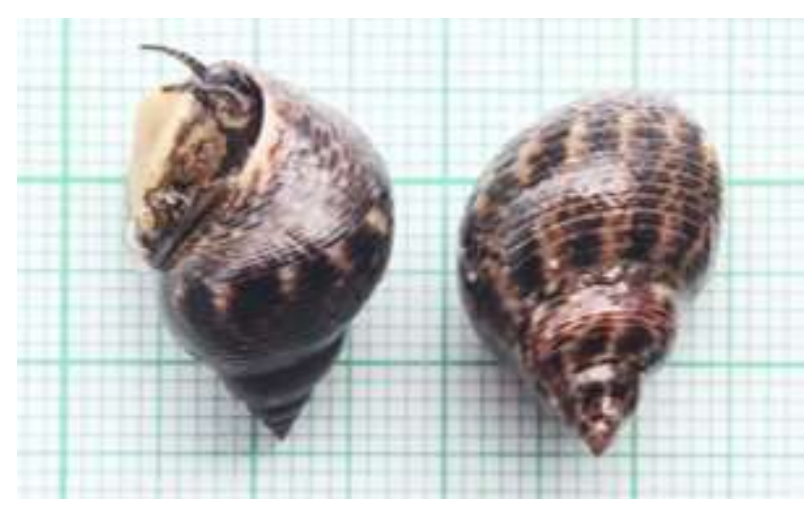

Littoraria scabra Linnaeus, 1758

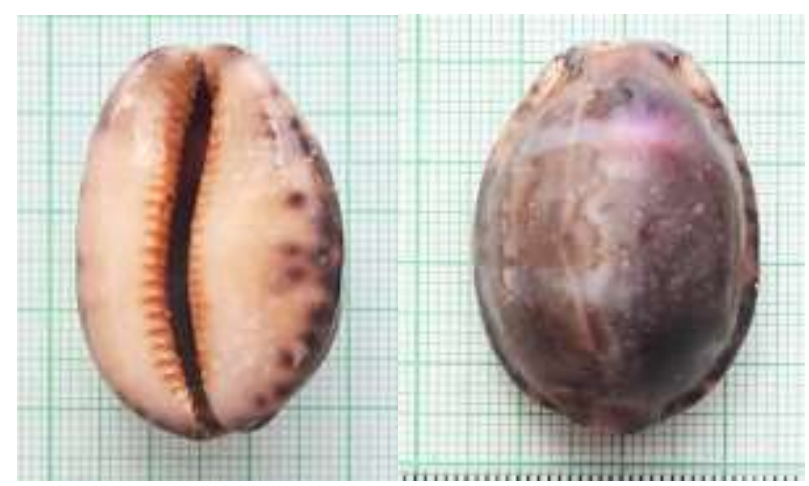

Cypraea arabica

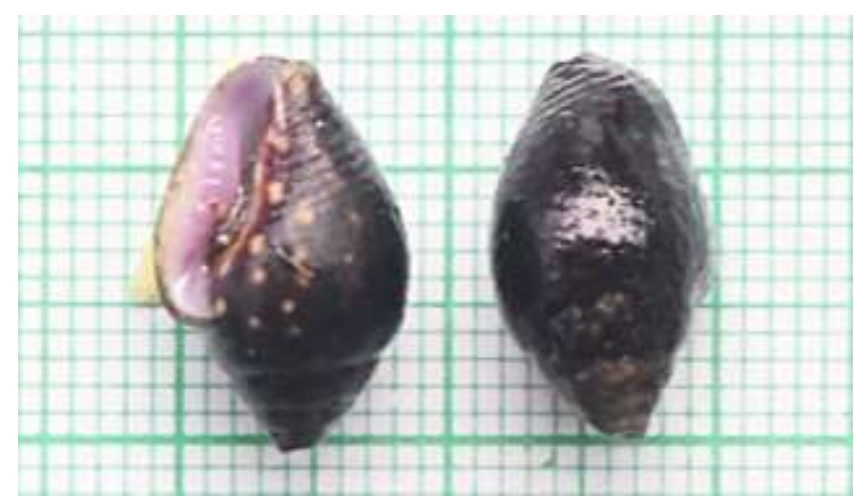

Strombus sp. 2

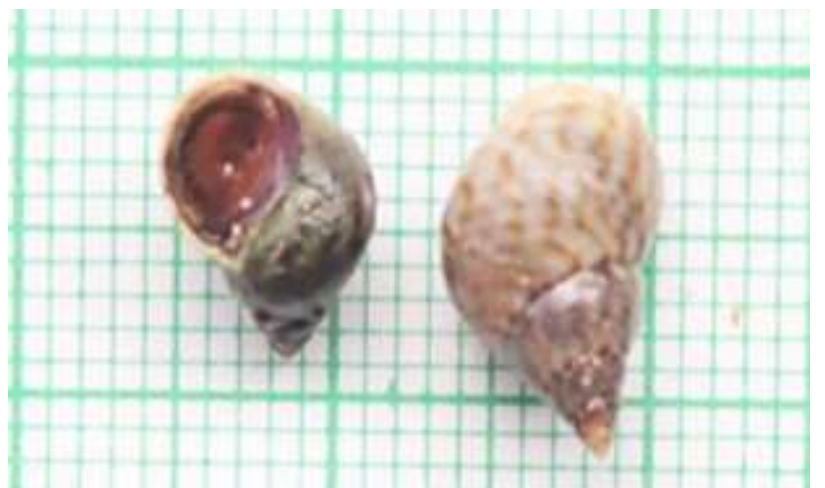

Littoraria angulifera Lamarck, 1822

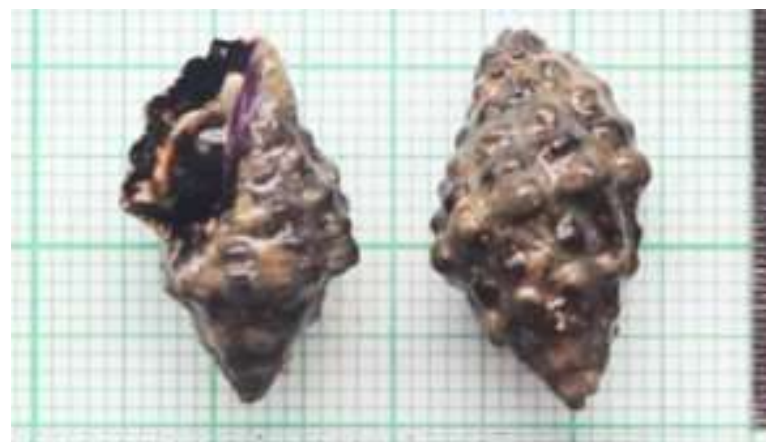

111111111111111111111+111111111111111

Neothais marginatra Blainville, 1832

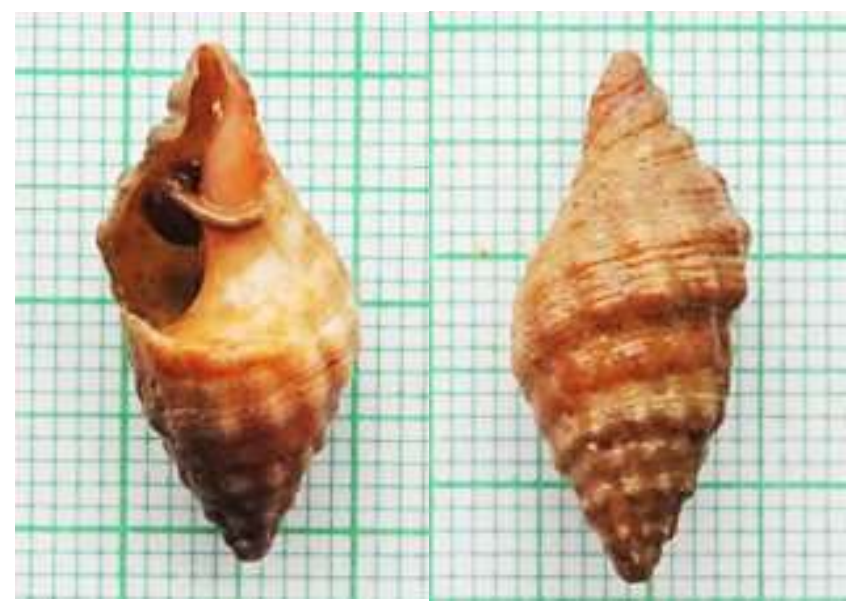

Ocinebrina aciculate

Gambar 3. Mesogastropoda dan Neogastropoda yang di temukan selama penelitian 
pada bagian anterior mulut cangkang. Kaki berukuran panjang $1,3 \mathrm{~cm}$, tidak memiliki bysus. Biasanya ditemukan di pesisir pantai, menempel pada batu di sepanjang garis pantai yang mengalami pasang surut.

\section{Ocinebrina aciculate}

Cangkang berjumlah satu dengan bentuk lonjong, strukturnya kuat, dan permukaannya berduri tumpul. Ukuran cangkang yaitu panjang $2,4 \mathrm{~cm}$; tinggi $1 \mathrm{~cm}$; dan lebar $1 \mathrm{~cm}$. Arah putaran cangkang ke kiri sebanyak 7 putaran. Mulut cangkang bergerigi sebanyak 5 buah. Operculum berwarna coklat kehitaman. Proboscis dengan siphon sepanjang $0,6 \mathrm{~cm}$. Ukuran siphon tidak sepanjang cangkang, yaitu $0,6 \mathrm{~cm}$. Canal siphon pendek, berukuran $0,4 \mathrm{~cm}$, berbentuk mencuat pada bagian anterior mulut cangkang. Kaki berukuran panjang $1,6 \mathrm{~cm}$, tidak memiliki bysus. Biasanya ditemukan di pesisir pantai, terutama di padang lamun.

\section{Keanekaragaman Mesogastropoda dan Neogastropoda}

Indeks keanekaragaman hayati dapat digunakan untuk menunjukkan struktur komunitas dan kestabilan ekosistem. Semakin tinggi indeks keanekaragaman hayati menunjukkan semakin stabil pula ekosistemnya. Indeks keanekaragaman mesogastropoda dan neogastropoda tergolong sedang (Tabel 2). Hal ini menunjukkan ekosistem di zona eulitoral kawasan pesisir Pulau Sembilan Kotabaru cukup stabil, dimana zona tersebut ditumbuhi sedikit padang lamun dan terumbu karang. Apabila dikaitkan dengan parameter lingkungan, menurut Fajeriadi et al (2018a) aspek parameter lingkungan di zona eulitoral pulau Sembilan tergolong baik sebagai habitat gastropoda.

Indeks keanekaragaman mesogastropoda dan neogastropoda tergolong sedang karena aktivitas masyarakat pesisir Pulau Sembilan ini hanya memanfaatkan siput-siputan sebagai alternative lauk ketika musim sulit ikan atau gelombang tinggi, sehingga nelayan tidak turun melaut. Menurut Bahri et al. (2015), suatu wilayah dengan aktivitas lingkungan yang baik serta didukung dengan pengelolaan yang baik akan meningkatkan kesehatan dan produktifitas ekosistem terumbu karang dilingkungan tersebut, karena secara tidak langsung terumbu karang akan terjaga dari ancaman lingkungan sekitar seperti limbah keluarga, pengeboman, serta racun ikan yang mempengaruhi terumbu karang.

Berdasarkan jumlah individunya, spesies mesogastropoda dan neogastropoda berbeda jauh dari archaeogastropoda. Spesies dengan nilai Pi tertinggi adalah Littoraria angulifera Lamarck, 1822. Spesies tersebut ditemukan secara berkelompok di batu-batu besar tepian pantai. Batu-batu di tepian pantai mengalami sedimentasi berupa substrat lumpur dan ditumbuhi lumut, sehingga Littoraria angulifera ditemukan dalam jumlah yang banyak pada zona tersebut. Riascos et al. (2010) \& Reid (2012) menjelaskan spesies dari genus Littoraria (Littorinidae) menghuni batuan, kayu apung, tanaman garam dan pohon bakau di zona intertidal di seluruh wilayah tropis dan subtropics.

Kemudian, spesies dengan nilai Pi terendah adalah Cypraea arabica; dan Ocinebrina aciculate. Cypraea spp. Umumnya beraktivitas mencari makan di dasar perairan. Kedua spesies ini ditemukan di sisa-sisa terumbu dan batu karang dasar perairan secara soliter. Hasil ini menunjukkan permasalahan zona eulitoral pesisir pantai Pulau Sembilan Kotabaru justru terjadi pada ekosistem terumbu karang. Menurut Purchon (1981) di antara Cypraeidae, spesies Cypraea arabica dan $C$. errones tersebar luas, cenderung ditemukan di hampir semua pantai di mana batubatu besar di bawah rata-rata permukaan laut.

Tabel 2. IndeksKeanekaragaman

\begin{tabular}{lccc}
\hline \multicolumn{1}{c}{ Spesies } & Ind & Pi & -Pi ln Pi \\
\hline Strombus Sp 1 & 20 & 0.118 & 0.253 \\
Strombus Sp 2 & 34 & 0.201 & 0.323 \\
Littoraria angulifera Lamarck, 1822 & 64 & 0.379 & 0.368 \\
Littoraria scabra Linnaeus, 1758 & 24 & 0.142 & 0.277 \\
$\begin{array}{l}\text { Cypraea arabica } \\
\text { Neothais marginatra } \text { Blainville, 1832 }\end{array}$ & 4 & 0.024 & 0.089 \\
Ocinebrina aciculata & 21 & 0.124 & 0.259 \\
\hline \multicolumn{1}{c}{ Jumlah Total } & 2 & 0.012 & 0.053 \\
\hline
\end{tabular}


Ekosistem terumbu karang Pulau Sembilan Kotabaru memang cukup luas, namun mengalami kerusakan di beberapa titik. Setidaknya, Fajeriadi et al, (2018b) melaporkan tahun 2013 terumbu karang masih ditemukan tumbuh menutupi dasar pantai di sekitar dermaga Pulau Sembilan, namun tahun 2016 dan 2017 keberadaan terumbu karang mulai menghilang. Hilangnya terumbu karang ini disebabkan adanya penangkapan ikan dari luar daerah yang menggunakan bom potasium dan candrang, pengambilan batu karang dan pasir secara ilegal. Menurut Santoso (2011) terumbu karang Indonesia mengalami berbagai tekanan dari aktivitas darat. Alih fungsi lahan meningkatkan pembuangan sedimen ke terumbu dan limbah menyebabkan polusi. Secara kumulatif, tekanan-tekanan ini secara signifikan menurunkan terumbu karang Indonesia dari waktu ke waktu.

\section{KESIMPULAN}

Ditemukan lima spesies Mesogastropoda dan dua spesies Neogastropoda di zona eulitoral kawasan pesisir Pulau Sembilan Kotabaru. Indeks keanekaragaman adalah 1.620 dengan kategori sedang, artinya ekosistem di kawasan tersebut tergolong stabil. Spesies dengan nilai Pi tertinggi adalah Littoraria angulifera Lamarck, 1822. Spesies tersebut ditemukan secara berkelompok di batu-batu besar tepian pantai yang mengalami sedimentasi lumpur organik. Spesies dengan nilai $\mathrm{Pi}$ terendah adalah Cypraea arabica dan Ocinebrina aciculate. Kedua spesies ini ditemukan beraktivitas secara soliter di terumbu dan batu karang dasar perairan. Rendahnya nilai Pi kedua spesies ini karena kondisi terumbu dan batu karang di zona tersebut sudah mengalami kerusakan.

\section{DAFTAR PUSTAKA}

Bahri, S., Rudi, E. \& Dewiyanti, I., 2015. Kondisi terumbu karang dan makroinvertebrata di Perairan Ujong Pancu, Kecamatan Peukan Bada, Aceh Besar. DEPIK Jurnal Ilmu-Ilmu Perairan, Pesisir dan Perikanan, 4(1).

Brown, K.M. \& Lydeard, C. 2010. Mollusca: gastropoda. In Ecology and classification of North American freshwater invertebrates: Academic Press. pp. 277-306.

Fachrul, M.F. 2012. Metode Sampling Bioekologi. Bumi Aksara, Jakarta.

Fajeriadi, H., Zaini, M. \& Dharmono. 2018a. Snails Diversity of Archaeogastropoda Order at the Eulittoral Zone in Pulau Sembilan, Kotabaru Regency. Prosiding Seminar
Nasional Lingkungan Lahan Basah Universitas Lambung Mangkurat; Banjarmasin, pp. 150-156.

Fajeriadi, H., Zaini, M. \& Dharmono. 2018b. SIPUT: Situs Tepi Laut Pulau Sembilan Kotabaru. Banjarmasin: Lambung Mangkurat University Press.

Febrita, E., Darmawati \& Astuti, J. 2015. Keanekaragaman Gastropoda dan Bivalvia Hutan Mangrove Sebagai Media Pembelajaran Pada Konsep Keanekaragaman Hayati Kelas X SMA. Jurnal Biogenesis. 11(2):119-128.

Goltenboth, F., Timotius, K.H., Milan, P.P. \& Margraf, J. 2012. Ekologi Asia Tenggara: Kepulauan Indonesia. Salemba Teknika, Jakarta.

Kurhe, A.R., Rodríguez, M.A. \& Suryawanshi, G.D. 2014. Vertical distribution and diversity of gastropods molluscs from intertidal habitats of the Ratnagiri coast Maharashtra, India. International Research Journal of Natural and Applied Sciences, 1(6):1-13.

Kusnadi, A., Hernawan, U.E. \& Triandiza, T. 2008. Moluska Padang Lamun Kepulauan Kei Kecil. Jakarta: LIPI Press.

Purchon, R.D., 1981. The marine shelled mollusca of West Malaysia and Singapore Part 1. General introduction and an account of the collecting stations. Journal of Molluscan Studies, 47(3):290-312.

Quintero-Galvis, J. \& Castro, L.R. 2013. Molecular Phylogeny of the Neritidae (Gastropoda: Neritimorpha) Based on the Mitochondrial Genes Cytochrome Oxidase I (Coi) and 16s rRNA. Acta biol. Colomb, 18(2):307-318

Reid, D.G. \& Williams, S.T. 2004. The subfamily Littorininae (Gastropoda: Littorinidae) in the temperate Southern Hemisphere: the genera Nodilittorina, Austrolittorina and Afrolittorina. Records of the Australian Museum. 56(1):75-122.

Reid, D.G., Dyal, P. \& Williams, S.T., 2012. A global molecular phylogeny of 147 periwinkle species (Gastropoda, Littorininae). Zoologica Scripta, 41(2):125136.

Riascos, J.M. \& Guzman, P.A., 2010. The ecological significance of growth rate, sexual dimorphism and size at maturity of Littoraria zebra and $L$. variegata (Gastropoda: Littorinidae). Journal of Molluscan Studies, 76(3):289-295. 
Romdhani, A.M., Sukarsono \& Susetyarini, Rr.E. 2016. Keanekaragaman Gastropoda Hutan Mangrove Desa Baban Kecamatan Gapura Kabupaten Sumenep sebagai Sumber Belajar Biologi. Jurnal Pendidikan Biologi Indonesia 2(2):161-167.

Santoso, A.D. 2011. Teknologi Konservasi dan Rehabilitasi Terumbu Karang. Jurnal Teknologi Lingkungan, 9(3):121-226

Soni, H.B. \& Thakur, K., 2015. Preliminary checklist of marine mollusks from Beyt Dwarka, Gulf Of Kutch (eco-sensitive zone), Gujarat, India. International Journal of Environment, 4(2):243-255.
Suratissa, D.M. \& Rathnayake, U., 2017. Effect of pollution on diversity of marine gastropods and its role in trophic structure at Nasese Shore, Suva, Fiji Islands. Journal of AsiaPacific Biodiversity, 10(2):192-198.

Tuheteru, M., Notosoedarmo, S. \& Martosupono, M. 2014. Distribusi Gastropoda di Ekosistem Mangrove. Prosiding Seminar Nasional Raja Ampat: A-151-A-156.

Yanto, R., Pratomo, A. \& Irawan, H., 2016. Keanekaragaman Gastropoda pada Ekosistem Mangrove Pantai Masiran Kabupaten Bintan. Repository Universitas Maritim Raja Ali Haji. 